\title{
Use of an environmentally oriented organic mineral fertilizer from liquid waste of pig farms in the cultivation of wheat
}

\author{
Tatiana Kolesnikova* and Marina Kulikova \\ Platov South-Russian State Polytechnic University (NPI), 346428, Rostov Region, Novocherkassk, \\ Prosveshcheniya, 132, Russia
}

\begin{abstract}
The article presents the results of a field vegetation experiment in the Rostov region on the cultivation of spring wheat of the "Zlata" variety with the use of an environmentally oriented organic mineral fertilizer from liquid waste of pig farms by the method of split plots with a randomized placement of variants in repetitions, the repetition of the experiment is three-fold. The agrochemical indicators of the soil before and after wheat cultivation at the horizons of $0-20$ and $20-40 \mathrm{~cm}$ are given. The scheme of carrying out the experiment, including different doses of organic mineral fertilizer application and a plan for cutting plots, is indicated. During the growing season, constant observations of the plants were carried out together with the care. The dynamics of the growth of wheat biomass in different periods of time from planting and its yield are presented. The influence of different doses of ecologically oriented organic mineral fertilizer from pig manure on the yield of spring wheat is estimated. According to the results of experimental data, the effective dose of organic mineral fertilizer application from pig manure was established$2 \mathrm{t} / \mathrm{ha}$. The yield of grain crops (wheat) per hectare was determined-49.2 c / ha. The spring wheat variety "Zlata", which is unusual for the Rostov region, gave a high yield when applying an environmentally oriented fertilizer, which proves its value both in agronomic and ecological terms. The absence of toxic effects on the soil of organic mineral fertilizers for heavy metals (copper, nickel. cadmium, lead), an increase in humus from $5.43 \%$ to $5.52 \%$. The assessment of the nutrient reserves in seeds and the effect of organic mineral fertilizer doses on the quality of spring wheat grain of the «Zlata» variety is given. The highest amount of gluten- $40.03 \%$ - was observed when using the fertilizer at a dose of $2 \mathrm{t} / \mathrm{ha}$.
\end{abstract}

In the Russian Federation in 2020, the Rostov region became the leading region in terms of the sown area occupied for wheat - about 2.87 million hectares instead of 2.81 in 2019. The area under wheat sowing is a record since the beginning of 2000, not only for the Rostov region, in the following years it is also planned to increase the gross harvest of grain crops with a yield of 30 or more quintals per hectare. To maintain the trend of increasing productivity, a set of measures aimed at preserving the agro-melioration capacity and

\footnotetext{
* Corresponding author t.kolesnikova@npi-tu.ru
} 
fertility of farmland is necessary. To develop the best agronomic approaches to avoid yield fluctuations and stabilize crop production systems, detailed knowledge of the factors that affect the stability of the resulting crop is needed. In addition to farming methods such as crop processing, crop rotation, variety selection, or plant protection measures, the supply of nutrients is one of the key factors affecting the improvement and stabilization of wheat yields. Currently, in the fields of the Russian Federation, mainly expensive mineral fertilizers are used. Along with the high cost, the application of mineral fertilizers alone has a number of significant disadvantages and cannot contribute to the most complete provision of soil with nutrient components and prevent deterioration of the structure of the fertile layer. Depleted and divested of microbial communities, the soil is not able to react and properly absorb incoming mineral fertilizers. Microbial communities increasingly dose, distribute, and convert incoming fertilizers into bioactive forms. As a result, only 25-30\% of the applied mineral fertilizers are absorbed by plants, while the other part is washed out and bound to the soil. Mineral fertilizers without an organic part work effectively only under favorable weather conditions, causing the dependence of plants on the conditions and doses of application. At the same time, there is a high agro-reclamation potential in the multi-tonnage liquid waste of pig farms. The concept of environmentally oriented agriculture should be based on resource-saving approaches to the reproduction of soil fertility and include the activation of the use of the natural biological potential of the prepared liquid waste of pig farms. Extensive research by scientists shows that the use of liquid waste from pig farms, both independently and in combination with mineral fertilizers, has a positive dynamic in recovering the fertility and agro-reclamation properties of soils [1-5]. The use of ecologically directed organic mineral fertilizers to improve the structure of the fertile soil layer and to steadily increase the yield of grain crops and, in particular, wheat, remains an urgent task in modern agriculture. Studies of scientists from various countries are devoted to solving this problem [6-11]. The results of a long-term field experiment presented in [6] stated that in all variants, additional manure application stabilized the wheat yield and provided the lowest agronomic risk for yield failure. In [7], it was noted that, although organic fertilizers are more environmentally friendly, they have too low a concentration of nutrients and slow release of nutrients to support crop production in a short time. In [8], it is proved that the use of organic fertilizers in combination with mineral fertilizers should be considered as an effective strategy for a sustainable wheat production system, contributing to the mitigation of negative environmental consequences. Studies [9] found that the replacement of mineral fertilizers with manure during wheat cultivation led to an increase in economic profit by $17.2 \%$, while the environmental impact decreased by $24.6 \%$. In source [10] is summarized information on the practices and concepts of organic farming, presents proposals for new methods of processing manure for agricultural use and alternatives to fertilizers. The results of studies [11] indicated that the use of manure is a viable strategy for regulating crop yields due to increased soil fertility. The authors of the article have developed methods for obtaining organic mineral fertilizers based on liquid waste from pig farms [12-14]. In 2019, the effectiveness of organic mineral fertilizer was evaluated at the D. N. Pryanishnikov Scientific Research Institute of Agrochemistry, when growing spring wheat of the "Zlata" variety in vessels under phytotron conditions. At the time of recording the harvest, the wheat plants were in the phase of starting to enter the tube. The vegetation experiment in vessels during the cultivation of spring wheat biomass "Zlata" showed the greatest increase in biomass (29\%) when using an environmentally oriented organic mineral fertilizer at a dose of $2 \mathrm{t} / \mathrm{ha}$.

To evaluate the agronomic and environmental impact indicators of the resulting organic mineral fertilizer, a small-scale vegetation experiment was conducted in 2020 in the field on a specially designated site in the Rostov region. The soil of the selected site is 
characterized by the indicators (in terms of sampling depth $0-20 \mathrm{~cm}$ and $20-40 \mathrm{~cm}$ ), presented in Table 1.

Table 1. The structure of the soil on the selected site

\begin{tabular}{|c|c|c|c|c|c|}
\hline \multirow{2}{*}{$\begin{array}{c}\text { Name of quality and safety } \\
\text { indicators, units of } \\
\text { measurement }\end{array}$} & \multicolumn{2}{|c|}{$\begin{array}{c}\text { The actual value } \\
\text { regulating the test } \\
\text { procedure, at a depth } \\
\text { of }\end{array}$} & \multicolumn{2}{|c|}{$\begin{array}{c}\text { Inaccuracy (with } \\
\text { confidence probability } \\
\mathrm{p}=0.95 \text { ) }\end{array}$} & $\begin{array}{c}\text { The } \\
\text { importance of } \\
\text { quality and } \\
\text { safety } \\
\text { indicators }\end{array}$ \\
\cline { 2 - 5 } & $0-20 \mathrm{~cm}$ & $20-40 \mathrm{~cm}$ & $0-20 \mathrm{~cm}$ & $20-40 \mathrm{~cm}$ & not rated \\
\hline Nitrate nitrogen, $\mathrm{mg} / \mathrm{kg}$ & 4,3 & 3,9 & $\pm 1,3$ & $\pm 1,2$ & not rated \\
\hline $\begin{array}{c}\text { Mobile phosphorus } \\
\text { compounds, } \mathrm{P}_{2} \mathrm{O}_{5}, \mathrm{mg} / \mathrm{kg}\end{array}$ & 25,9 & 20,1 & $\pm 5,2$ & $\pm 4,02$ & not rated \\
\hline $\begin{array}{c}\text { Exchange forms of } \\
\text { potassium } \mathrm{K}_{2} \mathrm{O}, \mathrm{mg} / \mathrm{kg}\end{array}$ & 655,0 & 575,0 & \pm 66 & \pm 58 & not rated \\
\hline Salt pH, units, eд & 7,6 & 7,6 & $\pm 0,2$ & $\pm 0,2$ & at least 2.0 \\
\hline $\mathrm{Humus,, \%}$ & 5,43 & 5,21 & $\pm 0,54$ & $\pm 0,52$ & 132,0 \\
\hline $\mathrm{Cu}$ & 20,5 & 21,8 & $\pm 3,9$ & $\pm 4,2$ & 130,0 \\
\hline $\mathrm{Pb}$ & 18,4 & 18,1 & $\pm 5,9$ & $\pm 5,8$ & 2,0 \\
\hline $\mathrm{Cd}$ & 0,23 & 0,22 & $\pm 0,09$ & $\pm 0,09$ & 80,0 \\
\hline $\mathrm{Ni}$ & 39,8 & 38,1 & $\pm 10,7$ & $\pm 10,3$ & \\
\hline
\end{tabular}

Field small-scale farming experience was laid in three-fold repetition. The layout of the options is randomized. We researched the effectiveness of four fertilizer systems (without fertilizers, environmentally oriented fertilizer from liquid waste of pig farms- $2 \mathrm{t} / \mathrm{ha}$ and 4 $\mathrm{t} / \mathrm{ha}$, mineral fertilizers NPK (equivalent to 2t/ha of the resulting fertilizer), fertilizer based on bird droppings) on the background without herbicide. The experiment was carried out according to the generally accepted method [15]. The dynamics of germination, growth and maturation of spring wheat when using various fertilizer systems is shown in Fig. 1.

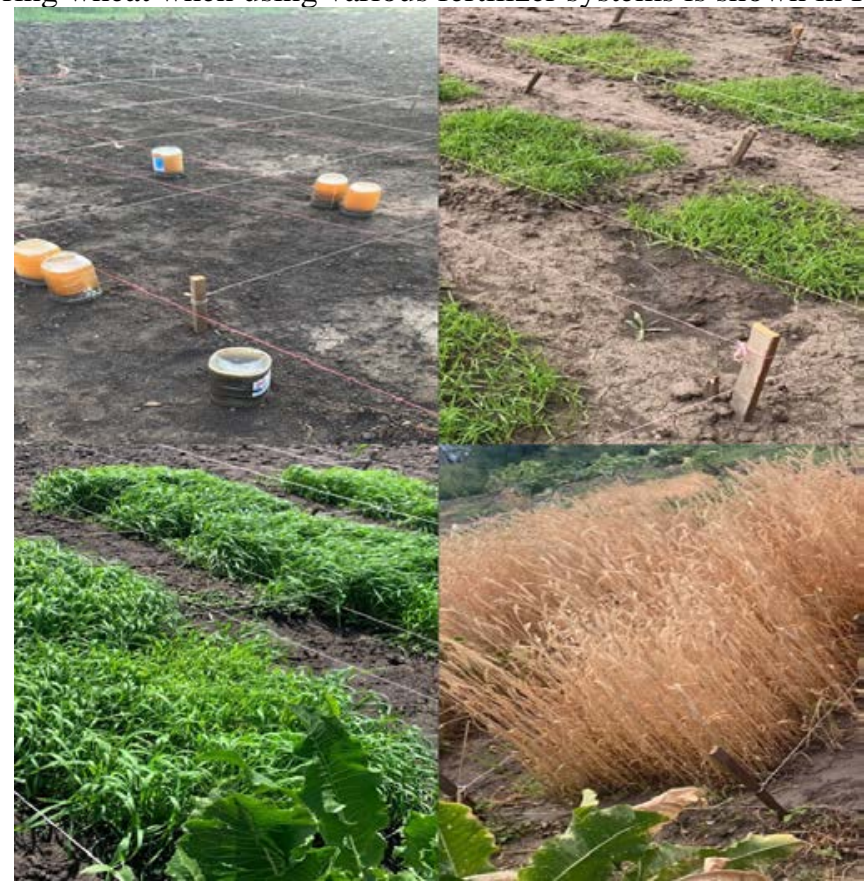

Fig. 1. Dynamics of germination, growth and maturation of spring wheat of the "Zlata" variety when using various fertilizer systems after $0,10,45,75$ days from sowing 
The yield of spring wheat of the "Zlata" variety was evaluated by a continuous division method in all repetitions of the experiment, based on absolutely pure products and standard grain moisture (14\%). In 2020, the agrometeorological conditions for the growth and formation of spring wheat grain "Zlata" were generally favorable, the growing season was characterized as warm with sufficient precipitation. The harvest was carried out in the first decade of August 2020. The statistical analysis of the level of wheat yield was also determined from the following elements: the number of ears, the number of grains in the ear, the absolute weight of the grain. The results of the research are presented in Table2.

Table2. The influence of the studied fertilizers on the yield of spring wheat of the "Zlata" variety»

\begin{tabular}{|c|c|c|}
\hline Experience scheme & Yield, c/ha & \pm for control \\
\hline Control without fertilizers & 32,4 & - \\
\hline $\begin{array}{c}\text { Ecologically oriented organic mineral } \\
\text { fertilizer at a dose of 2 t /ha }\end{array}$ & 49,2 & 16,8 \\
\hline $\begin{array}{c}\text { Ecologically oriented organic mineral } \\
\text { fertilizer at a dose of 4t /ha }\end{array}$ & 49,6 & 8,3 \\
\hline $\begin{array}{c}\text { Mineral fertilizer NPK, equivalent to 2t /ha } \\
\text { of the resulting fertilize }\end{array}$ & 40,7 & 11,2 \\
\hline Fertilizer based on bird droppings & 43,6 & \\
\hline $\mathrm{HCP}_{05}$ & 6,99 & \\
\hline
\end{tabular}

The yield per hectare in quintals was determined by the following formula [15]:

$$
\mathrm{Y}=(\mathrm{k} \cdot \mathrm{z} \cdot \mathrm{a}) / 10000
$$

the number of ears per $1 \mathrm{~m}^{2}$;

$\mathrm{z}$ - the number of grains in the ear;

a - the absolute weight of the grain, that is, the weight of 1000 grains, grams.

$$
\mathrm{Y}=(675 \cdot 12 \cdot 40) / 10000=32,4 \mathrm{c} / \mathrm{ha}
$$

The highest yield was observed when using an ecologically oriented organic mineral fertilizer at a dose of $4 \mathrm{t} /$ ha, but the most effective dose should be considered $2 \mathrm{t} / \mathrm{ha}$, since a slight increase in yield $(0.4 \mathrm{c} / \mathrm{ha})$ is associated with a twofold increase in the required amount of fertilizers. The yield increase in this variant of applying organic mineral fertilizer $2 \mathrm{t} /$ ha was $30.5 \%$. The determination of the mass of 1000 grains, equal to 39-40 g, allowed us to give a high estimate of the nutrient reserves in the seeds.

The introduction of an ecologically oriented fertilizer affects not only the productivity of spring wheat, but also the technological quality of the grain, with the highest content of protein and raw gluten Table 3.

Table 3. Wheat quality under different fertilizer systems

\begin{tabular}{|c|c|c|c|}
\hline Experience scheme & $\begin{array}{l}\text { Dry } \\
\text { matter,\% }\end{array}$ & $\begin{array}{c}\text { Protein,\% per } \\
\text { absolutely dry } \\
\text { substance }\end{array}$ & $\begin{array}{c}\text { The amount of } \\
\text { raw gluten, \% per } \\
\text { absolutely dry } \\
\text { substance }\end{array}$ \\
\hline $\begin{array}{c}\text { Control without fertilizers } \\
\begin{array}{c}\text { Ecologically oriented organic mineral fertilizer } \\
\text { at a dose of 2 t/ha }\end{array}\end{array}$ & 91,71 & 12,9 & 34,78 \\
\hline $\begin{array}{c}\text { Ecologically oriented organic mineral fertilizer } \\
\text { at a dose of 4t/ha }\end{array}$ & 91,95 & 16,56 & 40,03 \\
\hline $\begin{array}{c}\text { Mineral fertilizer NPK, equivalent to 2 t/ha of } \\
\text { the resulting fertilize }\end{array}$ & 91,60 & 16,59 & 40,02 \\
\hline Fertilizer based on bird droppings & 91,68 & 13,64 & 38,56 \\
\hline
\end{tabular}


We evaluated the agrochemical parameters of the soil on the plot with the introduction of an ecologically oriented organic mineral fertilizer at a dose of $2 \mathrm{t} / \mathrm{ha}$. The data obtained is presented in Table 4.

Table 4. Soil structure after applying an ecologically oriented organic mineral fertilizer at a dose of $2 t /$ ha

\begin{tabular}{|c|c|c|c|c|c|}
\hline $\begin{array}{c}\text { Name of quality } \\
\text { and safety } \\
\text { indicators, units of } \\
\text { measurement }\end{array}$ & \multicolumn{2}{|c|}{$\begin{array}{c}\text { The actual value } \\
\text { regulating the test } \\
\text { procedure, at a depth of }\end{array}$} & \multicolumn{2}{|c|}{$\begin{array}{c}\text { Inaccuracy (with } \\
\text { confidence probability } \\
\text { p=0.95) }\end{array}$} & $\begin{array}{c}\text { The importance of } \\
\text { quality and safety } \\
\text { indicators }\end{array}$ \\
\cline { 2 - 5 } & $0-20 \mathrm{~cm}$ & $20-40 \mathrm{~cm}$ & $0-20 \mathrm{~cm}$ & $20-40 \mathrm{~cm}$ & not rated \\
\hline $\begin{array}{c}\text { Nitrate nitrogen, } \\
\text { mg/kg }\end{array}$ & 37,5 & 30,5 & $\pm 7,5$ & $\pm 6,1$ & not rated \\
\hline $\begin{array}{c}\text { Mobile phosphorus } \\
\text { compounds, } \mathrm{P}_{2} \mathrm{O} \text { 5, } \\
\mathrm{mg} / \mathrm{kg}\end{array}$ & 113,0 & 100,0 & $\pm 16,9$ & \pm 15 & not rated \\
\hline $\begin{array}{c}\text { Exchange forms of } \\
\text { potassium } \mathrm{K}_{2} \mathrm{O}, \\
\mathrm{mg} / \mathrm{kg}\end{array}$ & 950,0 & 925,0 & \pm 95 & \pm 92 & not rated \\
\hline Salt pH, units, ед & 7,2 & 7,1 & $\pm 0,2$ & $\pm 0,2$ & at least 2.0 \\
\hline $\mathrm{Humus, \%} \%$ & 5,52 & 5,32 & $\pm 0,55$ & $\pm 0,53$ & 132,0 \\
\hline $\mathrm{Cu}$ & 18,1 & 18,5 & $\pm 3,5$ & $\pm 3,5$ & 130,0 \\
\hline $\mathrm{Pb}$ & 12,1 & 11,7 & $\pm 3,9$ & $\pm 3,7$ & 2,0 \\
\hline $\mathrm{Cd}$ & 0,21 & 0,18 & $\pm 0,08$ & $\pm 0,07$ & 80,0 \\
\hline $\mathrm{Ni}$ & 21,6 & 20,3 & $\pm 5,3$ & $\pm 5,5$ & \\
\hline
\end{tabular}

Thus, the spring wheat variety "Zlata", which is unusual for the Rostov region, gave a high yield when applying an ecologically oriented fertilizer, which proves its value both in agronomic and ecological terms. When assessing the state of the soil after applying an ecologically oriented organic mineral fertilizer from the liquid waste of pig farms, an increase in such indicators as nitrate nitrogen, mobile phosphorus compounds and potassium exchange forms was revealed. At the same time, the content of heavy metals (copper, lead, cadmium and nickel) in concentrations much lower than normal indicates the safety of fertilizers based on liquid waste from pig farms.

\section{References}

1. B.A. Ghulam, A.S. Bouba, T.S. Ansar, A.Sh. Shamim-ul-Sibtain, Sh.S. Gamil, M.Al Solaimanid,Q.H. Nadeem, A.Kh. Shahzad, T.Sh. Afzal et al. Journal of Environmental Management 241 (2019), Pages 468-478.

2. J. Wilhelmus, M. Pullensa, P. Sørensen, Bo Melander, J. Eivin d Olesena, European Journal of Agronomy 122 (2021),126169.

3. Y.Lin, GuipingYe, Y. Kuzyakov, D. Liu, J.bo Fan, W. Ding. SBB, 134(2019), Pages 187-196.

4. K. Ylivainio, A. Lehti, J.Jermakka, H. Wikberg, E. Turtola. Science of The Total Environment, 773 (2021), 145618.

5. J. Doltra, P. Gallejones, J.E.Olesen, S. Hansen, R.B. Frøseth, M. Krauss, J. Stalenga, K. Jończyk, A. Martínez-Fernández, G.C. Pacini. Field Crops Research 233 (2019), Pages 1-11.

6. J. Macholdt, H-P Piepho, B. Honermeier. European Journal of Agronomy 102 (2019), Pages 14-22. 
7. H. Song, J. Wang K. Zhang, M. Zhang, R. Hui, T. Sui, L.Yang, W.Du, Zh. Dong. Journal of Environmental Management 263 (2020), 110384

8. L. Zhang, Zh. Liang, Yu. Hu, U. Schmidhalter, W. Zhang, S. Ruan, X. Chen. Journal of Cleaner Production 287(2021), 125572.

9. Sh. Li, J. Wu, X. Wang, L. Ma. Journal of Cleaner Production 271 (2020), 122683.

10. J.D. Flores-Félix, E. Menéndez, R. Rivas, M. EncarnaciónVelázquez. Organic Farming (Global Perspectives and Methods) Chapter 9 (2019), Pages 269-315.

11. A. Cai, M. Xu, B. Wang, W. Zhang, G. Liang, E. Hou,Y. Luo. STR 189 (2019), Pages 168-175.

12. E. Gribut, M. Kulikova, O. Surgko, T. Kolesnikova and D. Monastic. EurAsian Journal of BioSciences 14 (2020), Pages. 575-579.

13. T. Kolesnikova, M. Kulikova, E. Gribut. EurAsian Journal of BioSciences 14, (2020), Pages 829-834.

14. T. Kolesnikova, M. Kulikova, D. Kasharin, D. Monastirskiy// IOP Conference Series: EES 548(3) (2020), 032013.

15. B. Dospehov. Field experiment technique (with the basics of statistical processing of research results)- M.: Book on deman(2012)-352p. ISBN 978-5-458-23540-2. 